\title{
Long term follow up after surgery for benign intracranial cysts in children
}

\author{
Katrin KM Rabiei,, Roberto Doria Medina, Mats Högfeldt, Carsten Wikkelsö, Magnus Tisell \\ From Hydrocephalus 2015 \\ Banff, Canada. 18-21 September 2015
}

Arachnoid cysts are cystic malformations in cerebrospinal axis found in both adults and children. While most arachnoid cysts are asymptomatic and usually go undetected, some cause symptoms and warrant surgical treatment. In this prospective study we aimed to describe the result of short- and long term follow up in children referred to our center with a cystic malformation.

\section{Methods}

27 pediatric patients ( $13 \mathrm{f}, 14 \mathrm{~m}$, mean age $9,4 \mathrm{y}$ ) with denovo cysts were consecutively included during a 5 year period. Reason for initial investigation was headache, seizures, endocrine dysfunction, macrocephaly, balance disturbance and/or dizziness, trauma, cognitive disturbance and syncope. 22 patients underwent surgical treatment after initial evaluation with either open- or endoscopic fenestration of the cyst wall. Cyst volume was measured pre- and postoperatively with OsiriX software. Short term follow up was conducted 3 months and long term follow up 8, 6 years (7-10, 5 y) postoperatively.

\section{Results}

$60 \%(13 / 22)$ of the patients were improved after the short term - and 82\% (18/22) after the long term follow up considering at least one major complaint. Operated cysts had a mean preoperative volume of $60 \mathrm{ml}(5-225 \mathrm{ml})$ which postoperatively reduced with average of $56 \%$ at 3 month follow up. There was no significant difference in postoperative cyst volume between patients who improved and those who did not. Headache and imbalance improved significantly in the long-term follow up but not in the short term. Some individuals improved in Cognitive function, seizures and endocrine dysfunction. There was no permanent postoperative morbidity.

\footnotetext{
* Correspondence: katrinrabie@gmail.com

Hydrocephalus research unit, Institution of Neuroscience, Sahlgrenska Academy, Sweden
}

Submit your next manuscript to BioMed Central and take full advantage of:

- Convenient online submission

- Thorough peer review

- No space constraints or color figure charges

- Immediate publication on acceptance

- Inclusion in PubMed, CAS, Scopus and Google Scholar

- Research which is freely available for redistribution 